\title{
Harvestmen (Arachnida: Opiliones) of open biotopes in the Poloniny National Park (north-eastern Slovakia)
}

\author{
Ivan MIHÁL ${ }^{1}$, Peter GAJDOŠ² ${ }^{2}$ nd Pavel ŽILA ${ }^{3}$
}

\begin{abstract}
${ }^{1}$ Institute of Forest Ecology, Slovak Academy of Sciences, Štúrova 2, 96053 Zvolen, Slovakia; e-mail: mihal@savzv.sk ${ }^{2}$ Institute of Landscape Ecology, Slovak Academy of Sciences, Bratislava, branch Nitra, Akademická 2, P.O.Box 23/B, 949 01, Nitra, Slovakia; e-mail: p.gajdos@savba.sk

${ }^{3}$ Faculty of Natural Sciences, Constantine the Philosopher University, Tr. A. Hlinku 1, 94974 Nitra, Slovakia; e-mail: zilapavel@gmail.com
\end{abstract}

\begin{abstract}
Opiliofauna of open biotopes in the Poloniny National Park is presented. The biotopes include the variably utilized or successively overgrowing grasslands. During the period 2011-2013, we found 21 species of harvestmen which represent $60 \%$ of the Slovak opiliofauna. The highly eudominant species was Phalangium opilio. The open and sunny biotopes as meadows and pastures proved to be typical habitats for P. opilio and Oligolophus tridens. Other dominant species were: Trogulus nepaeformis and Lacinius ephippiatus. The Carpathian endemics: Paranemastoma kochi and Ischyropsalis manicata as well as thermophilic species Egaenus convexus, Lacinius horridus and Zachaeus crista were also found in the study sites.
\end{abstract}

Key words: opiliofauna, non-forest biotopes, meadows, Bukovské vrchy Mts

\section{INTRODUCTION}

The eastern mountain range in Slovakia is Bukovské vrchy, situated at the Polish and Ukrainian borders. Its greater area is a part of the Poloniny National Park (NP). This Slovak Park, together with the adjacent protected area in Poland (i.e. the Bieszczady National Park and two landscape parks) and in Ukraine (the National Nature Park of Uzh River) is included in the trans-border East Carpathian Biosphere Reserve. The three-border region belongs to the Outer Eastern Carpathian flysch belt area. The latest information about the opiliofauna of the Poloniny NP, as well as other areas of the Bukovské vrchy Mts, was presented by Mašán (1998), Mihál et al. (2003), Mihál (2004), Stašiov (2004a, 2004b), Mihál \& Mašán (2006) and Bezděčka \& Bezděčková (2011). On the Polish side of the Bukovské vrchy Mts, the research on harvestmen in Bieszczady NP was carried out by Rafalski (1961), Staręga (1966, 1975, 2000), Pawłowski \& Sterzyńska (1994), Rozwałka (2012) and Rozwałka \& Staręga (2012a, 2012b). On the Ukrainian side of the Bukovské vrchy Mts, the harvestmen research was presented by Chevrizov (1979). The faunistic data in these papers suggest that the harvestmen fauna of each of the parts of the region is similar, not only in its zoogeographical origin and species representation but also high species diversity.

In the northern and eastern Slovakia, harvestmen were also studied in the mountain ranges, close to the Bukovské vrchy Mts, e.g. the Ondavská vrchovina highlands (Stašiov et al. 2003, Mihál \& Mašán 2006, Stašiov \& Kertys 2008), the Vihorlat Mts (Šilhavý 1950, Mašán 2005, Mihál \& Mašán 2006), the Slanské vrchy Mts (Maršálek 1999) and in the Tatras (Šilhavý 1974, Mihál \& Mašán 2006, Mihál et al. 2010, Mihál \& Astaloš 2011). The distribution and ecology of harvestmen in Slovakia including the Bukovské vrchy Mts and other mountain ranges of eastern Slovakia were summarized by Stašiov (2004b) in monographic work. The opiliofauna in forest biotopes of the Poloniny NP were studied by Mihál et al. (2003). 
In this paper, we present the results of the faunistic study on opiliofauna in the open biotopes of the Poloniny NP, i.e. variably utilized or successively overgrowing grasslands, mostly mesophilic meadows so-called "poloniny". In recent years has increased the number of Slovak papers on Opiliones of open biotopes, e.g. meadows in different stages of succession, ruderal areas and also forest calamities or clearcuts (Mihál 1997, 2013, Stašiov 2005, Mihál \& Astaloš 2011). On the meadows in the Poloniny NP were recorded 200 spider species of 23 families (Žila \& Gajdoš 2012a, 2012b); among them 31 species were classified as endangered and rare in the Red List of Spiders of Slovakia (Gajdoš \& Svaton̆ 2001) and two species were categorized as critically endangered. We did not expect to find a large opiliofauna species richness or record endangered species; we complete and enhance the fragmented knowledge.

\section{MATERIAL AND METHODS}

The harvestmen of the open biotopes in the Poloniny NP were collected at 20 sites, once a month, from 12 Jul 2011 to 23 Apr 2013. The material (2452 individuals) was gathered by pitfall trapping. As pitfall trap we used a 0.7 -liter jar (diameter $8 \mathrm{~cm}$ ) with $4 \%$ formaldehyde solution. There were 100 traps (five traps per site). The traps with non-freeze solution functioned also during winter and they were emptied until April. The dominance index (D) for species on each locality was calculated (Losos et al. 1984) only for the data from 2011, when the highest abundance of individuals was found. Dominance classes ( $D>10$ - eudominant, $5<\mathrm{D}<10$ - dominant, $2<\mathrm{D}<5$ - subdominant, $1<\mathrm{D}<2$ - recedent, $1<\mathrm{D}$ - subrecedent) were arranged according Tischler's classification (1976). The material from 2012-2013 was reviewed only for newly found species. Harvestmen were identified according to the morphological keys (Martens 1978, Šilhavý 1956, 1971). The personal collection of the first author was also used for comparisons. The majority of material was preserved in $70 \%$ ethanol and deposited in the Institute of Forest Ecology SAS Zvolen.

\section{STUDY AREA}

The harvestman material of the Poloniny NP was gained from sites, where spiders were monitored for long term in the non-forest biotopes (cf. Žila \& Gajdoš 2012a, 2012b). We merged the sites to eight main localities, because of similarity of biotopes, short distance in the field as well as small and non-unified size of the study area (e.g. from $0.39 \mathrm{~m}^{2}$ to $112 \mathrm{~m}^{2}$ in the Ruské locality). The characteristics of the studied sites are presented below. Abbreviations: L1-L20 (locality label), CA (cadastral area), GPS (geographical coordinates), DFS (a code of the square in Slovak Fauna Databank), ALT m a.s.l (altitude) and B (biotope).

L1 - Bzaná, CA: Kolbasov; GPS: 490.843'N, 22²2.637'E; DFS: 6900c; ALT: 375; B: mesophilic lowland and upland hay meadows, alliance Arrhenatherion elatioris, assoc. PooTrisetetum flavescentis.

L2 - Kolbasov, CA: Kolbasov; GPS: $49^{\circ} 0.431^{\prime} \mathrm{N}, 2^{\circ} 22.997^{\prime} \mathrm{E}$; DFS: 6900c; ALT: 302; B: waterlogged upland and mountain meadows, alliance Calthion, assoc. Cirsietum rivularis.

L3 - Nová Sedlica-1, CA: Nová Sedlica; GPS: 49².554'N, 22³1.155'E; DFS: 6901c; ALT: 427; B: waterlogged upland and mountain meadows, alliance Calthion, assoc. Cirsietum rivularis.

L4 - Nová Sedlica-2, CA: Nová Sedlica; GPS: 49².574'N, 22³1.213'E; DFS: 6901c; ALT: 428; B: mesophilic lowland and upland hay meadows, alliance Arrhenatherion elatioris. 
L5 - Nová Sedlica-3, CA: Nová Sedlica; GPS: 49².560'N, 22³1.202'E; DFS: 6901c; ALT: 433; B: mesophilic lowland and upland hay meadows, alliance Arrhenatherion elatioris, assoc. Poo-Trisetetum flavescentis.

L6 - Príslop-1, CA: Príslop; GPS: 49².345'N, 22²19.240'E; DFS: 6999d; ALT: 514; B: mesophilic lowland and upland hay meadows, alliance Arrhenatherion elatioris, assoc. Pastinaco sativae-Arrhenatheretum elatioris.

L7 - Príslop-2, CA: Príslop; GPS: 49².352'N, 22º19.252'E; DFS: 6999d; ALT: 508; B: mesophilic lowland and upland hay meadows, alliance Arrhenatherion elatioris, assoc. Pastinaco sativae-Arrhenatheretum elatioris.

L8 - Ruské-1, CA: Ruské; GPS: 49⒏646'N, 22²1.228'E; DFS: 6800c; ALT: 910; B: mountain flower meadows and pastures, alliance Nardo-Agrostion tenuis, assoc. Hypochaerido uniflorae-Nardetum strictae, Campanulo abietinae-Nardetum, BetonicoAgrostietum ass. nova.

L9 - Ruské-2, CA: Ruské; GPS: 49⒏225'N, 22²0.466'E; DFS: 6800c; ALT: 622; B: mountain flower meadows and pastures, alliance Nardo-Agrostion tenuis, assoc. Achilleo striactae-Calamagrostietum arundinaceae.

L10 - Ruské-3, CA: Ruské; GPS: 49⒎970'N, 22 ${ }^{\circ 0} 20.443$ 'E; DFS: 6800c; ALT: 568; B: mountain flower meadows and pastures, alliance Calamagrostion arundinaceae, assoc. Acetoso-Deschampsietum.

L11 - Ruské-4, CA: Ruské; GPS: 497.786'N, 22²0.466'E; DFS: 6800c; ALT: 570; B: waterlogged upland and mountain meadows, alliance Calthion, assoc. Cirsietum rivularis.

L12 - Ruské-5, CA: Ruské; GPS: 49².453'N, 22²0.475'E; DFS: 6800c; ALT: 535; B: mesophilic lowland and upland hay meadows, alliance Arrhenatherion elatioris, assoc. PooTrisetetum flavescentis.

L13 - Ruské-6, CA: Ruské; GPS: 49²7.225'N, 22²0.444'E; DFS: 6800c; ALT: 504; B: nitrophilic ruderal vegetation outside of the human habitation, alliance Galio-Alliarion, assoc. Cherophyletum aromatici.

L14 - Ruské-7, CA: Ruské; GPS: 496.873'N, 22²0.440'E; DFS: 6800c; ALT: 548; B: mesophilic lowland and upland hay meadows, alliance Arrhenatherion elatioris, assoc. PooTrisetetum flavescentis.

L15 - Ruské-8, CA: Ruské; GPS: 496.652'N, 22²0.418'E; DFS: 6800c; ALT: 482; B: successively changed waterlogged upland and mountain meadows, alliance Calthion, assoc. Scirpetum sylvatici.

L16 - Ruské-9, CA: Ruské; GPS: 496.398'N, 22²0.412'E; DFS: 6800c; ALT: 454; B: nitrophilic ruderal vegetation outside of the human habitation, alliance Galio-Alliarion, assoc. Cherophyletum aromatici.

L17 - Sihla, CA: Ruské; GPS: 496.229'N, 22²0.031'E; DFS: 6899d; ALT: 439; B: waterlogged upland and mountain meadows, alliance Calthion x Molinion caerulae.

L18 - Starina, CA: Starina; GPS: $49^{\circ} 2.729^{\prime} \mathrm{N}, 2^{\circ} 14.944{ }^{\prime} \mathrm{E}$; DFS: 6999c; ALT: 374; B: mesophilic waterlogged upland and mountain meadows, alliance Violion, assoc. Campanulo rotundifoliae-Dianthetum deltoidis.

L19 - Topol'a-1, CA: Topol'a; GPS: 49²1.562'N, 22²1.184'E; DFS: 6900c; ALT: 362; B: mesophilic lowland and upland hay meadows, alliance Arrhenatherion elatioris, assoc. Pastinaco sativae-Arrhenatheretum elatioris.

L20 - Topol'a-2, CA: Topol'a; GPS: 49²1.544'N, 22²1.164'E; DFS: 6900c; ALT: 359; B: mesophilic lowland and upland hay meadows, alliance Arrhenatherion elatioris, assoc. Pastinaco sativae-Arrhenatheretum elatioris. 


\section{RESULTS AND DISCUSSION}

We recorded 21 Opiliones species, which represent $60 \%$ of the harvestman fauna known from Slovakia (35 species, cf. Šestáková \& Mihál 2014). The most species (19) we found at the locality Ruské (Table 1) with varied and diversified plant biotopes: L8-L16 farmed meadows and waterlogged meadows with ruderal vegetation.

Table 1. The harvestmen species found in different locations (BZ - Bzaná, KO - Kolbasov, NS - Nová Sedlica, PR Príslop, RU - Ruské, SI - Sihla, ST - Starina, TO - Topol'a); values of dominance index (D) in harvestmen assemblages in pitfall traps material at particular localities of the Poloniny NP in 2011; asterisk (*) refers to the species found at selected localities in 2012 or 2013 (the dominance in 2011 has not been evaluated for these species).

\begin{tabular}{|c|c|c|c|c|c|c|c|c|c|c|c|}
\hline & Locality & $\mathrm{BZ}$ & $\mathrm{KO}$ & NS & PR & RU & SI & ST & $\mathrm{TO}$ & & \\
\hline No. & Species & L1 & $\mathrm{L} 2$ & L3-5 & L6-7 & L8-16 & L17 & L18 & L19-20 & $\Sigma$ & $\mathrm{D}$ \\
\hline 1 & N. lugubre & & & 0.30 & 1.37 & 2.14 & & 11.72 & & 53 & 2.16 \\
\hline 2 & P. kochi & & 10.0 & * & & 0.12 & & 3.91 & 5.71 & 10 & 0.41 \\
\hline 3 & M. chrysomelas & & & 1.50 & & 0.83 & & 0.10 & 2.86 & 32 & 1.31 \\
\hline 4 & D. scabrum & 7.69 & & 0.60 & & 1.84 & & 1.56 & 8.57 & 42 & 1.71 \\
\hline 5 & T. nepaeformis & 17.31 & 10.0 & 20.36 & 17.81 & 3.03 & 1.45 & 44.53 & & 201 & 8.20 \\
\hline 6 & T. tricarinatus & & & 2.40 & 2.74 & 1.37 & & 0.78 & & 34 & 1.39 \\
\hline 7 & I. manicata & $*$ & & 1.80 & & & & 1.56 & & 8 & 0.33 \\
\hline 8 & P. opilio & 50.0 & 40.0 & 34.73 & 75.34 & 68.01 & 89.13 & 0.78 & 82.90 & 1498 & 61.09 \\
\hline 9 & O. saxatilis & & & & $*$ & * & & & $*$ & * & * \\
\hline 10 & P. bucephalus & & & & & 0.36 & & & & 6 & 0.24 \\
\hline 11 & P. pallidus & & & $*$ & & $*$ & & $*$ & & $*$ & * \\
\hline 12 & R. triangularis & 15.39 & & & & 2.73 & 3.62 & & $*$ & 59 & 2.41 \\
\hline 13 & L. palpinalis & & & & & 0.95 & 0.72 & 0.78 & & 18 & 0.73 \\
\hline 14 & Z. crista & $*$ & & & & $*$ & & & & $*$ & * \\
\hline 15 & E. convexus & 9.62 & & & 2.74 & 3.21 & & & & 61 & 2.50 \\
\hline 16 & O. tridens & & & 31.44 & & 7.07 & 3.62 & 21.10 & & 256 & 10.44 \\
\hline 17 & L. horridus & & 40.0 & 0.60 & & & & & & 6 & 0.24 \\
\hline 18 & L. dentiger & & * & & & $*$ & & & & $*$ & * \\
\hline 19 & L. ephippiatus & & & 5.01 & & 7.43 & 0.72 & 3.91 & & 148 & 6.04 \\
\hline 20 & M. morio & & & 1.20 & & 0.83 & 0.72 & & & 19 & 0.77 \\
\hline 21 & N. semproni & & & & & 0.06 & & & & 1 & 0.04 \\
\hline & $\Sigma$ individuals & 52 & 10 & 334 & 73 & 1682 & 138 & 128 & 35 & 2452 & \\
\hline & $\Sigma$ species & 7 & 5 & 13 & 6 & 19 & 7 & 12 & 6 & 21 & \\
\hline
\end{tabular}

Phalangium opilio occurred as a highly eudominant species (Table 1). This is heliophilic and eurytopic harvestman (Stašiov 2004b, Mihál et al. 2014). Open and sunny biotopes, meadows and pastures proved to be the optimal habitats for P. opilio. Similarly, Oligolophus tridens $(\mathrm{D}=10.44)$ belonged to eudominant harvestmen on meadows and pastures of the Poloniny NP. Trogulus nepaeformis $(\mathrm{D}=8.20)$ and Lacinius ephippiatus $(\mathrm{D}=6.04)$ occurred as dominant species. Nemastoma lugubre, Rilaena triangularis and Egaenus convexus were also recorded. However, the domination of $T$. nepaeformis was unexpected because the species was previously known mainly from rather humid and shady forest habitats (cf. Mihál et al. 2003, Stašiov 2004b). This species, together with Nemastoma lugubre can occur also in thinned forest stands and ecotones as well as in open biotopes where both of these species colonise more shady and moist microhabitats. These two species were found in such microhabitats as vineyards, farmed upland, mountain meadows and in clear-cuts (Mihál 1997, 2013, Mihál \& Černecká 2014, Mihál et al. 2014). Similar abundance of $N$. lugubre was found by Stašiov (2005) in the xerothermic meadow in the Štiavnické vrchy Mts, where this species was occured as dominant together with P. opilio and Zachaeus crista and both of these species were considered as typical xerothermic species (by Stašiov, l.c.).

The hygrophilic and forest species, i.e. Paranemastoma kochi, Ischyropsalis manicata and Platybunus bucephalus were not abundant on the mesophilic meadows of the Poloniny NP. 
Moreover, only five specimens of mountain species Platybunus pallidus appeared at three localities in 2012. On the other hand, we assumed higher dominance of Mitopus morio, Nelima semproni and Lacinius horridus, which do not avoid ecotones or non-forest stands. Likewise, other xerophilic and thermophilic species Lacinius dentiger, Opilio saxatilis and Zachaeus crista occurred rarely and were recorded for the first time in 2012. For example, only three specimens of $L$. dentiger were recorded at two localities, 14 specimens of $O$. saxatilis at three localities and five specimens of Z. crista at two localities. Also Siro carpaticus was found on four localities in the Poloniny NP, Opilio parietinus was found on one locality, Gyas titanus on nine, Astrobunus laevipes on two and Leiobunum aff. rupestre was found on eleven localities.

The common occurrence of xerophilic harvestmen Egaenus convexus and Zachaeus crista together with typical mountain and hygrophilic Ischyropsalis manicata and Paranemastoma kochi was documented from same mosaic habitats. Their co-existence may be due to the ecotone character of the stands - the xerophilic meadows vegetation or shrubs, hedges and remnants of old orchards were adjacent to river alluvium and wetlands (Mihál et al. 2003).

The harvestman species richness of the Poloniny NP currently covers 26 species that were recorded in various biotopes. Apart from our collections from non-forest stands in the years 2011 to 2013, other species that we were collecting mainly in the forest biotopes of the Poloniny NP in the years 1998 to 2002, were also included in the Table 2 (cf. Mihál et al. 2003). With each species, we present the biotope preference, where a given species was the most abundant in the specific climatic-ecological conditions in the Poloniny NP.

Table 2. Harvestmen of the Poloniny NP and their habitat preference for forest (closed canopy forests, virgin forests, monocultures, forest spring stands), ecotone (forest edges, hedgerows, gardens, game refuges, open canopy forests, forest roads) and open habitats (mountain meadows, clear cuts, forest roads, seat of fire, ruderal plant communities, human settlements). Preferences were evaluated on the base on the data from the following papers: Mihál et al. (2003, 2010), Mihál \& Astaloš (2011) and the data from the present study, according to whether the species had been considered to be dominant $(\bullet)$ or not (०).

\begin{tabular}{|c|c|c|c|c|}
\hline No. & Species & Forest & Ecotone & Open habitat \\
\hline 1 & Siro carpaticus Rafalski, 1956 & $\bullet$ & 0 & \\
\hline 2 & Nemastoma lugubre (Müller, 1776) & $\bullet$ & • & ○ \\
\hline 3 & Paranemastoma kochi (Nowicki, 1870) & $\bullet$ & o & ○ \\
\hline 4 & Mitostoma chrysomelas (Hermann, 1804) & - & 0 & o \\
\hline 5 & Dicranolasma scabrum (Herbst, 1799) & • & • & ○ \\
\hline 6 & Trogulus nepaeformis (Scopoli, 1763) & $\bullet$ & $\bullet$ & $\bullet$ \\
\hline 7 & Trogulus tricarinatus (Linnaeus, 1767) & $\bullet$ & $\bullet$ & $\circ$ \\
\hline 8 & Ischyropsalis manicata L. Koch, 1865 & $\bullet$ & o & o \\
\hline 9 & Phalangium opilio Linnaeus, 1761 & & ० & $\bullet$ \\
\hline 10 & Opilio parietinus (De Geer, 1778) & & ० & $\bullet$ \\
\hline 11 & Opilio saxatilis C. L. Koch, 1839 & & ० & $\bullet$ \\
\hline 12 & Platybunus bucephalus (C. L. Koch, 1835) & • & $\bullet$ & $\circ$ \\
\hline 13 & Platybunus pallidus Šilhavý, 1938 & $\bullet$ & ० & \\
\hline 14 & Rilaena triangularis (Herbst, 1799) & o & $\bullet$ & $\bullet$ \\
\hline 15 & Lophopilio palpinalis (Herbst, 1799) & $\bullet$ & $\bullet$ & o \\
\hline 16 & Zachaeus crista (Brullé, 1832) & o & $\bullet$ & $\bullet$ \\
\hline 17 & Egaenus convexus (C. L. Koch, 1835) & ○ & $\bullet$ & $\bullet$ \\
\hline 18 & Oligolophus tridens (C. L. Koch, 1836) & $\bullet$ & $\bullet$ & $\bullet$ \\
\hline 19 & Lacinius ephippiatus (C. L. Koch, 1835) & $\bullet$ & $\bullet$ & $\bullet$ \\
\hline 20 & Lacinius horridus (Panzer, 1794) & ○ & $\bullet$ & $\bullet$ \\
\hline 21 & Lacinius dentiger (C. L. Koch, 1848) & ○ & $\bullet$ & $\bullet$ \\
\hline 22 & Mitopus morio (Fabricius, 1799) & $\bullet$ & $\bullet$ & $\bullet$ \\
\hline 23 & Gyas titanus Simon, 1879 & $\bullet$ & o & \\
\hline 24 & Astrobunus laevipes (Canestrini, 1872) & $\bullet$ & $\bullet$ & o \\
\hline 25 & Leiobunum aff. rupestre (Herbst, 1799) & ○ & $\bullet$ & $\bullet$ \\
\hline \multirow[t]{2}{*}{26} & Nelima semproni Szalay, 1951 & $\circ$ & $\bullet$ & $\bullet$ \\
\hline & Total number of species found as dominant & 16 & 17 & 14 \\
\hline
\end{tabular}


However, we expected even greater number of harvestman species. We have not found, for example, Opilio dinaricus which was present in the vicinity of the Vihorlat Mts (Šilhavý 1950, 1968), Leiobunum rotundum or L. limbatum - the last one was found in the town of Snina, at the foot of the Bukovské vrchy Mts (Bezděčka \& Bezděčková 2011). Moreover, Chevrizov (1979) found three other species, from Ukraine, right next to the Slovakian border, i.e. Carinostoma elegans (Mukačevo), Holoscotolemon jaqueti and Paranemastoma silli (Užhorod). We believe that the occurrence of these harvestmen in the Bukovské vrchy Mts is possible, as was the case with $C$. elegans, which was recorded so far from one site in western Slovakia in 2014 (Šestáková \& Mihál 2014).

The previous data on harvestmen in the Poloniny NP (Mihál et al. 2003) referred to forest and non-forest stands within 36 selected localities. Then, Stašiov (2004a) found nine species of harvestmen, between of them the typical mountain species Gyas titanus and also the Carpathian endemics, e.g. P. kochi and Ischyropsalis manicata. Several species of harvestmen among those given in Table 1 and those mentioned by Stašiov (2004a), were collected also by Mihál (2004) and Mihál \& Mašán (2006) at localities Zboj and Ruské in the the Poloniny NP. The latest data on occurrence of the rare harvestmen species in the Slovakian territory, i.e. Siro carpaticus and Leiobunum limbatum, come from the Polish side - the Bieszczady NP (Rozwałka 2012, Rozwałka \& Staręga 2012a). Earlier, Staręga (1966, 1975) stated a big similarity between the opiliofauna of the Polish Bieszczady, the Slovakian Poloniny Mts and the Vihorlat Mts, as well as the opiliofauna of other close mountain ranges in Orava, the Tatras and Pieniny.

The intensively studied harvestman fauna of the Ondavská vrchovina Highlands (Stašiov et al. 2003, Stašiov \& Kertys 2008) included 17 species also found by us in the Poloniny NP. Šilhavý (1950), Mašán (2005) and Mihál \& Mašán (2006) showed a similar species richness of harvestmen from the nearby Vihorlat Mts. The most harvestman species, i.e. 21 species (except L. dentiger, $N$. semproni, P. pallidus, S. carpaticus and Z. crista) - recorded in the Poloniny NP (Table 2) — was found in the other mountain ranges, e.g. in Slánske vrchy Mts (Maršálek 1999) and in the Tatras (Šilhavý 1974, Mihál \& Mašán 2006, Mihál et al. 2010, Mihál \& Astaloš 2011). Overall, 26 harvestmen species known in the Poloniny NP can occur here thanks to the specific mosaic structure, preserved in the Bukovské vrchy Mts. This may be an effect of the earlier traditional farming, both in forest and non-forest biotopes on the whole protected area.

\section{ACKNOWLEDGEMENTS}

This work was partially supported by the Scientific Grant Agency VEGA (projects No. 2/0035/13, 2/0184/11) as well as by the projects FCVV FPV UKF Nitra and UGA No. VII/2012. The authors wish to thank to Jana Edwards for translation of the paper.

\section{REFERENCES}

BEZDĚČKA P. \& BEZDĚČKOVÁ K. 2011. Leiobunum limbatum - nový sekáč (Opiliones) pro Slovensko. Folia faunistica Slovaca 16: 31-34.

CHEVRIZOV B.P. 1979. On the fauna of Opiliones of western regions of the European part of the USSR. Entomologicheskoje obozrenie 68: 426-430. [In Russian].

GAJDOŠ P. \& SVATOŇ J. 2001. Červený (ekosozologický) zoznam pavúkov (Araneae) Slovenska. Ochrana prírody 20: 80-86.

Losos B., GULIČKA J., LELLÁK J. \& PELIKÁN J. 1984. Ekologie živočichů. SPN, Praha, 320 pp.

MARŠÁLEK P. 1999. Niekol'ko poznámok k faune koscov (Opilionida) Slanských vrchov. Natura Carpatica 40: $225-230$.

MARTENS J. 1978. Weberknechte, Opiliones. Die Tierwelt Deutschlands, G. Fischer Verlag, Jena, 64, 464 pp.

MAŠÁN P. 1998. First record of Siro carpaticus (Opiliones, Cyphophtalmi, Sironidae) from Slovakia. Biologia 53: 650.

MAŠÁn P. 2005. Prvý nález kosca Siro carpaticus (Opiliones, Cyphophtalmi, Sironidae) vo Vihorlate. Telekia 3: 28. 
MiHÁL I. 1997. Harvestmen (Opilionida) in a brush stand and fir-beech forest of the Kremnické vrchy mountains. Biologia 52: 191-194.

MıнÁL I. 2004. Faunistické správy zo Slovenska - Opiliones: Nemastomatidae, Dicranolasmatidae, Trogulidae, Phalangiidae. Entomofauna Carpathica 16: 83.

MıHÁL I. 2013. Kosce (Arachnida: Opiliones) historických štruktúr pol’nohospodárskej krajiny v okolí Liptovskej Tepličky (Nízke Tatry). In: KRUMPÁLOVÁ Z. (ed.), 11. Arachnologická konferencia. Nové trendy vo výskume pavúkovcov. Zborník abstraktov, 11.9-15.9.2013, Východná, FPV UKF Nitra, ÚKE SAV Nitra, SARAS, o.z., pp. 41-43.

MiHÁL I. \& AstALOŠ B. 2011. Harvestmen (Arachnida, Opiliones) in disturbed forest ecosystems of the Low and High Tatras Mts. Folia oecologica 38: 89-95.

MiHÁL I. \& ČERnECKÁ L'. 2014. Kosce (Arachnida, Opiliones) NPR Boky a PR Rohy a ich okolia (stredné Slovensko). Folia Faunistica Slovaca 19: 49-55.

MiHÁL I., GAJDOŠ P., DANKANINOVÁ D. \& ČERnECKÁ L'. 2014. Kosce (Opiliones) fragmentárnych spoločenstiev vo vinohradníckej krajine Svätý Jur (Malé Karpaty). Folia Faunistica Slovaca 19: 9-14.

MihÁL I., KoRENKO S. \& GAJDOŠ P. 2010. Harvestmen (Arachnida, Opiliones) of the Tatra mountains (Slovakia). Acta Rerum Naturalium 8: 31-36.

MıнÁL I. \& MAŠÁN P. 2006. Príspevok k poznaniu koscov (Opiliones) stredného a východného Slovenska. Natura Carpatica 47: 89-96.

MiHÁl I., MAŠÁn P. \& Astaloš B. 2003. Kosce - Opiliones. In: MAŠÁN P. \& Svatoň J. (eds), Pavúkovce Národného parku Poloniny - Arachnids of the National Park Poloniny, ŠOP SR Banská Bystrica, Správa NP Poloniny, Snina, pp. 127-142.

PAWŁOWSKI J. \& STERZYŃSKA M. 1994. Cenne gatunki i zagrożone nisze lądowych bezkręgowców w polskiej części MRB „Karpaty Wschodnie“. Roczniki Bieszczadzkie 3: 57-73.

RAFALSKI J. 1961. Prodromus Faunae Opilionum Poloniae. Prace Komisji Biologicznej 25: 35-47.

RozWAŁKA R. 2012. Is Siro carpaticus Rafalski, 1956 (Arachnida: Opiliones) really a rare harvestmen species? Fragmenta Faunistica 55: 169-175.

RozWALKA R. \& StARĘGA W. 2012a. Distribution of Leiobunum limbatum L. Koch, 1861 (Opiliones: Sclerosomatidae) in Poland. Fragmenta Faunistica 55: 177-183.

RozWAŁKA R. \& StARĘGA W. 2012b. Distribution of harvestmen of the genus Paranemastoma Redzikorzev, 1936 (Opiliones: Nemastomatidae) in Poland. Annales Universitatis Mariae Curie-Skłodowska, Lublin - Polonia, vol. LXVII 2, sectio C: 7-20.

StARĘGA W. 1966. Kosarze (Opiliones) Bieszczad. Fragmenta Faunistica 13: 145-157.

StaręGa W. 1975. Opiliones - Kosarze (Arachnoidea). Fauna Polski 5: 1-195.

STARĘGA W. 2000. Check-list of harvestmen (Opiliones) of Poland. Available at www.arachnologia.edu.pl/kosarze.html [2 Feb 2014].

STAŠIOV S. 2004a. Poznámky ku koscom (Opiliones) NPR Stužica (Bukovské vrchy). In: MiDRIAK R. (ed), Biosférické rezervácie na Slovensku V., Zborník referátov z 5. národnej konferencie o biosférických rezerváciách SR, 29-30.9.2004, Nová Sedlica, TU Zvolen, pp. 139-142.

STAŠIOv S. 2004b. Kosce (Opiliones) Slovenska. Vedecké štúdie, 3/2004/A, Technická univerzita, Zvolen, 119 pp.

STAŠIOV S. 2005. Harvestmen communities on two hills in the Štiavnické vrchy Protected Landscape Area, Slovakia (Opiliones). Folia oecologica 32: 15-21.

STAŠIOV S. \& KERTYS Š. 2008. Spoločenstvá koscov (Opiliones) a mnohonôžok (Diplopoda) Breznickej mokrade. Acta Facultatis Ecologiae Zvolen 18: 59-68.

Stašiov S., MARŠAleK P., MihÁl I., MAšÁN P., Astaloš B. \& JarAB M. 2003. Kosce (Opiliones) Ondavskej vrchoviny. Natura Carpatica 44: 261-266.

ŠESTÁKOVÁ A. \& MiHÁL I. 2014. Carinostoma elegans new to the Slovakian harvestmen fauna (Opiliones, Dyspnoi, Nemastomatidae). Arachnologische Mitteilungen 48: 16-23.

ŠILHAVÝ V. 1950. Sekáči východního Slovenska. Entomologické Listy (Folia entomologica) 13: 99-106.

ŠILHAVÝ V. 1956. Sekáči - Opilionidea. Fauna ČSR, NČSAV, Praha, 7, 274 pp.

ŠILHAVÝ V. 1968. Př́íspěvek k faunistice sekáčů (Opilionidae) Slovenska. Zprávy Československé společnosti entomologické př̀ ČSAV 4: 63-64.

ŠILHAVÝ V. 1971. Sekáči - Opilionidea. In: DANIEL M. \& ČERNÝ V. (eds), Klíč zvířeny ČSSR IV, Academia, Praha, 33-49 pp.

ŠILHAVÝ V. 1974. Opilionidea. In: Zborník prác o Tatranskom národnom parku. Osveta, Martin, 16: 81-85.

TISCHLER W. 1976. Einfürung in die Ökologie. Gustav Fischer Verlag, Stuttgart, 307 pp.

ŽILA P. \& GAJDOŠ P. 2012a. Changes in composition of the ground living spider communities in non-forest habitats in the Poloniny after 12 years (Slovakia). In: KunTNER M. et al. (eds), 27th European Congress of Arachnology. Abstract Book. Ezlab, Ljubljana, Slovenia, 164 pp.

ŽILA P. \& GAJDOŠ P. 2012b. Epigeické pavúčie spoločenstvá vybraných nelesných ekosystémov Národného parku Poloniny. In: KubovČík V. \& StAŠIOV S. (eds), Zoológia 2012, 18. Feriancove dni. Zborník príspevkov z vedeckého kongresu, SZS pri SAV, TU Zvolen, pp.185-186. 


\section{STRESZCZENIE}

\section{[Kosarze (Arachnida: Opiliones) otwartych biotopów Parku Narodowego Połoniny (pólnocno-wschodnia Słowacja)]}

Autorzy przedstawiają wyniki badań kosarzy środowisk otwartych w Parku Narodowym Połoniny. Są to tereny zagospodarowane lub sukcesywnie zarastające obszary trawiaste, głównie mezofile łąki. Łącznie 21 gatunków kosarzy zebrano w latach 2011-2013, co stanowi $60 \%$ gatunków dotychczas wykazanych. Phalangium opilio okazał się eudominantem (61,09\%). Otwarte i słoneczne biotopy, łąki i pastwiska, stanowiły typowe środowisko występowania $P$. opilio. Eudominantem był także Oligolophus tridens (10,44\%). Pozostałymi dominatami były Trogulus nepaeformis (8,2\%) i Lacinius ephippiatus (6,04\%). Odnotowano również endemity karpackie: Paranemastoma kochi i Ischyropsalis manicata, jak również gatunki ciepłolubne Egaenus convexus, Lacinius horridus i Zachaeus crista. W pracy prezentowany jest aktualny stan wiedzy o opiliofaunie PN Połoniny (łącznie 26 gatunków) w odniesieniu do typu biotopu oraz najliczniej występujących gatunków. 